\title{
ALLELOPATHY AS AN INHIBITION FACTOR IN ORNAMENTAL TREE GROWTH: IMPLICATIONS FROM THE LITERATURE
}

\author{
by Timothy A. Chick ${ }^{1}$ and J. James Kielbaso ${ }^{2}$
}

\begin{abstract}
Allelopathy is the process whereby plants produce toxins that limit the growth of other plant species. Forest ecology and agronomy research has dealt with this phenomenon for some time, but there is a dearth of inquiry about allelopathy in ornamental and shade trees. A review of the literature suggests that herbaceous ground-cover toxins may interfere with nutrient uptake by damaging or destroying root cells, root hairs, and mycorrhizae. Soil texture appears to be a determinant in the extent of damage. Trees on poorly drained soils may be severely damaged, whereas those on well-drained sites may be less affected. Allelopathic factors interact with competitive and environmental factors. Cultural treatments, such as mulching and herbiciding, reduce allelopathic effects as well as competition and environmental stresses. Allelopathic mitigation enhances nutrient uptake, reducing the need for tree fertilization.

Keywords. Allelopathy; competition; inhibition; tree; ornamental.
\end{abstract}

Many shade-tree studies describe the effects of plant competition for limited resources such as water, nutrients, sunlight, and space. Rarely addressed is the role of chemically induced growth regulation. However, crop scientists, ecologists, and woodland forest researchers have recognized plant toxin influences for some time. The lack of information and testing related to phytotoxins and urban trees led to this review (Chick 1991).

Early reports noted negative effects on the survival and growth of tomatoes caused by black walnut (Juglans nigra) toxins as early as 1881 (Rice 1984). In 1937, Molisch coined the term "allelopathy," referring to biological interactions (both stimulatory and inhibitory) among all types of plants, including microorganisms (Rice 1984). The term "interference" has been used when it is unclear whether competitive or chemical influences are affecting plant growth (Muller 1969; Rice 1984).

Allelochemicals are metabolic byproducts and are introduced into the environment by volatilization from leaves and fruits, leaching from leaves, root exudation, and release from decomposing plant cells (Figure 1). Microorganisms may also transform organic chemicals in the soil into plant toxins.

Much of the allelopathy research has focused on seed germination and seedling growth and survival. Early plant development is more easily dealt with in the lab, greenhouse, and nursery than is the growth of older and larger woody plants. Hence, there is a substantial body of agricultural literature identifying allelochemicals that cause conflicts between crops and between weeds and crops. Ecological succession and forest regeneration can be studied in a similar manner.

\section{Allelopathy in Woody Plants}

The death of larger trees caused by toxins produced by adjacent trees or herbaceous ground cover occurs in nature, although infrequently, and is a dramatic example of allelochemical action. Black walnut natural products resulted in the death of 22- to 25-year-old white pine (Pinus strobus) and red pine ( $P$. resinosa) (Fisher 1978), 8- to 13-year-old black alder (Alnus rugosa) (Rietveld et al. 1983) and whips of white birch (Betula spp.) (Gabriel 1975).

Abnormally slow growth of larger forest trees, such as black cherry (Prunus serotina) (Horsley 1977a), sugar maple (Acer saccharum) (Fisher et al. 1978), and black spruce (Picea mariana) (Peterson 1965), had been observed but could not be attributed solely to competitive interactions. Ground-cover leachates were then tested against seedlings of these species, and chemical growth inhibition was clearly demonstrated. Walters and Gilmore (1976) examined the effects of tall fescue (Festuca arundinacea) leachates on the height growth of 10-year-old sweetgum ( $\mathrm{Li}$ quidambar styraciflua) and determined that most of the growth inhibition was allelopathic and not 


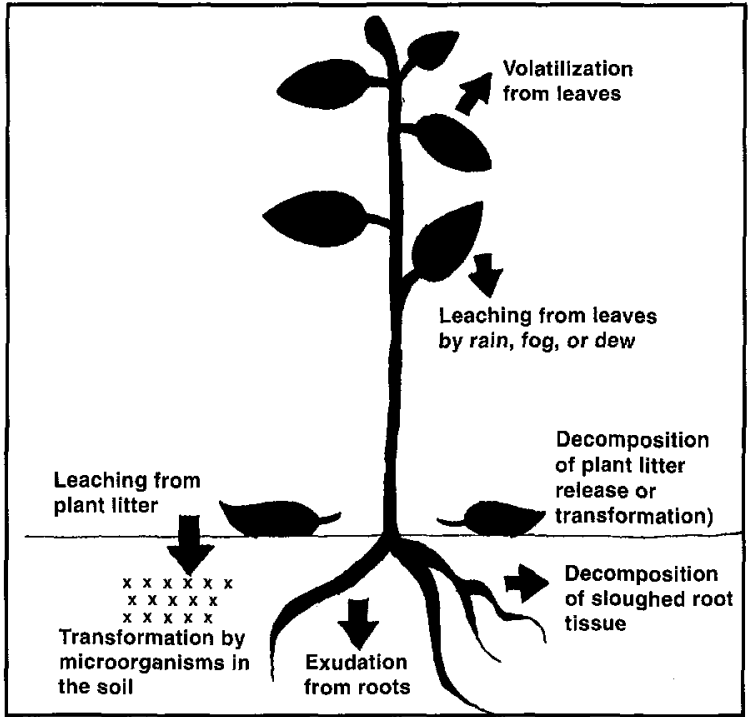

Figure 1. Environmental routes of entry (modified from Burke 1987, in Chick 1991).

competitive. Another report found that leachates of Kentucky bluegrass (Poa pratensis), red fescue (Festuca rubra), and perennial ryegrass (Lolium perenne) inhibited flowering dogwood (Cornus florida) and forsythia (Forsythia intermedia) plants, while competition for water and nutrients was a minor factor (Fales and Wakefield 1981).

Allelochemicals can cause growth inhibition by affecting physiological processes such as respiration, cell division, and water and nutrient uptake (Einhellig 1986). Mycorrhizae are commonly associated with forest tree roots and are necessary for normal uptake functions. Some evidence suggests that allelochemicals can disrupt the uptake process by damaging the root cells or hairs or by inhibiting mycorrhizal development (Weston and Putnam 1986; Perry and Choquette 1987). For example, black spruce root cells were destroyed by leachates from the leaves of sheep laurel (Kalmia augustifolia) (Peterson 1965). Agricultural researchers found inhibited root growth and root-hair formation on soybeans (Glycine max) treated with aqueous extracts of quackgrass (Agropyron repens) (Weston and Putnam 1986). Impaired absorption was suspected when phosphorus and nitrogen deficiencies were found in the leaves of sweetgum treated with tall fescue leachates (Walters and Gilmore 1976). Buchholtz (1971) found deficient levels of nitrogen and potassium in corn watered with quackgrass solutions. He suggested that inhibition of nutrient uptake and, to a lesser degree, water uptake, are important allelopathic modes of action.

\section{Factors Influencing Inhibition}

Although allelochemicals occur commonly in nature, biological, chemical, and environmental factors can influence the ability of a toxin to affect the growth of a particular plant. Five factors merit consideration.

First, specific plant toxins affect only particular species. For example, goldenrod (Solidago spp.) allelochems dramatically affected the growth and survival of black cherry (Horsley 1977a) and sugar maple (Fisher et al. 1978) but did not affect black birch (Betula lenta) and yellow birch (B. alleghaniensis) (Horsley 1987). Black walnut was implicated in the death of pine and birch, but it did not affect autumn olive (Elaeagnus umbellata) (Ponder 1987).

The presence of species that have been reported as allelopathic should be cause for concern when they are growing in the rooting zone of trees. Along with Kentucky bluegrass, red fescue, and perennial rye, lawn weeds such as tall fescue, quackgrass, crabgrass (Digitaria sanguinalis), foxtail (Setaria spp.), common chickweed (Stellaria media), and goosegrass (Eleusine indica) are potential chemical-producing plants. At least 80 plants have been identified by Putnam and Weston (1986) that provide adverse allelopathic effects in agricultural systems and could be suspect when growing with woody plants. Table 1 presents a condensed list of species that conflict with each other, along with a list of those that are compatible.

A second factor involves the size of a toxinproducing plant and its proximity to a sensitive tree. A mixed plantation of black walnut and black alder coexisted for 8 to 13 years prior to decline and death of the alder from the black walnut toxin, juglone (Rietveld et al. 1983). The density of offending herbaceous ground covers necessary for damage to trees of various sizes is uncertain. 
Table 1. Documented allelopathic conflicts in ornamental plants and allelopathically compatible species (adapted from Chick 1991).

\begin{tabular}{|c|c|}
\hline Allelopathic species & Examples of sensitive species \\
\hline Black walnut & $\begin{array}{l}\text { Pines (Austrian, white, Scotch, } \\
\text { red), apple, white birch }\end{array}$ \\
\hline Balsam poplar & Green alder \\
\hline Sassafras & Boxelder, elm, silver maple \\
\hline Black cherry & Red pine, red maple \\
\hline Sugar maple & Yellow birch, white spruce \\
\hline Southern red oak & Sweetgum \\
\hline Sycamore maple & Yellow birch \\
\hline Tall fescue & $\begin{array}{l}\text { Black walnut, sweetgum, } \\
\text { white ash }\end{array}$ \\
\hline Foxtail and smooth brome & Populus spp. \\
\hline Goldenrod and aster & $\begin{array}{l}\text { Sugar maple, red pine, tulip } \\
\text { poplar, black cherry }\end{array}$ \\
\hline Perennial rye & $\begin{array}{l}\text { Apple, forsythia, flowering } \\
\text { dogwood }\end{array}$ \\
\hline $\begin{array}{l}\text { Red fescue and Kentucky } \\
\text { bluegrass }\end{array}$ & $\begin{array}{l}\text { Azalea, barberry, yew, } \\
\text { forsythia, flowering dogwood }\end{array}$ \\
\hline Colonial bentgrass & $\begin{array}{l}\text { Azalea, barberry, yew, } \\
\text { forsythia }\end{array}$ \\
\hline $\begin{array}{l}\text { Rhododendron and } \\
\text { sumac }\end{array}$ & Douglas-fir \\
\hline \multicolumn{2}{|c|}{$\begin{array}{l}\text { Documented allelopathically compatible species } \\
\text { Black walnut and autumn olive } \\
\text { Redbud, oak, elm and hackberry } \\
\text { Kentucky bluegrass and northern red oak } \\
\text { Kentucky bluegrass and tulip poplar } \\
\text { Goldenrod, wild carrot, crown vetch and black alder } \\
\text { Aster, goldenrod, yellow and black birch }\end{array}$} \\
\hline
\end{tabular}

Seasonal variation in the toxicity of allelochemicals is a third well-reported factor. Fall foliage tends to release more potent allelochemicals than do fresh, green, spring foliage (Fisher et al. 1978; Petranka and McPherson 1979). Because unmaintained areas such as lowuse parks, vacant lots, and rights-of-way tend to accumulate decaying ground-cover vegetation, substantial amounts of potent allelochemicals may be released, which could inhibit tree growth.

A fourth factor involves chemical magnification. The concentration of specific allelochemicals, when applied singly, may be insufficient to cause injury to a sensitive plant. However, numerous experiments have shown that combinations of these same compounds can produce additive or synergistic effects that are inhibitory (Einhellig 1989). Asplund (1969) showed a hundredfold increase in plant inhibition with a mixture of only 2 chemicals. Therefore, ground covers consisting of sev- eral species of allelopathic plants may produce a more toxic association than any of the individual species alone (Einhellig 1989).

Plant stress caused by high temperature or by water or nutrient deficiencies also magnifies allelopathic processes (Rice 1984; Einhellig 1989). Toxin-producing plants can generate more chemicals when under stress, and trees that are sensitive to specific allelochemicals may become more so when stressed (Rice 1984; Einhellig 1989).

The last factor involves the mediation of allelochemicals in the soil. Except for some volatiles, edaphic factors are crucial in determining the fate of a toxin in the soil and its potential impact on sensitive plants.

Forest research provides suggestions for how allelopathy might work in urban soils. Juglone toxins from black walnut trees inter-planted with red and white pines caused severe dieback or mortality of the pines on sites with poorly drained (Fisher 1978) or clay soils (Rietveld 1982). Conversely, pines growing with walnut trees on welldrained, sandy soils showed no damage. The explanation for this phenomenon is based on the concept of "allelochem pool size" (Hoagland and Williams 1985). Pool size refers to the concentration level of soil toxins available to damage sensitive species. The accumulation and depletion of toxins in the soil is affected by factors such as soil type, drainage, aeration, temperature, and microbial activity.

Colloidal clay soils are able to adsorb most allelochemicals (Fisher 1987). Because clay soils drain poorly, toxin leaching is minimized. By contrast, coarse, well-drained, sandy soils would maximize leaching.

Soil microorganisms ingest carbon-based allelochemicals as energy sources, and metabolic decomposition can render the chemicals nontoxic to plants. When sandy soils are well drained and aerated, which is often the case, they encourage aerobic microorganisms that accelerate degradation of toxins. The wet moisture regime associated with poorly aerated clay soils discourages microbial growth and resultant toxin decomposition. Hence, toxin sensitive plants may be at higher risk when planted in heavy soils (DeBell 1970; Rietveld et al. 1983). 


\section{Cultural Mitigation of Allelopathy}

The evidence pointing to the competitive disadvantages of trees in turf has failed to dissuade those who want manicured lawns right up to the bases of trees (Green and Watson 1989). Past practice dictated the addition of fertilizer to compensate for nutrient competition where trees and turf coexist. This approach, however, may be costly and futile because turfgrass phytotoxins may interfere with the ability of tree roots to absorb nutrient elements. Grass and weed control can be achieved by herbicide application or mulching, either with organic or inorganic materials. These methods accomplish the goal of allelochemical reduction, allowing for optimal nutrient uptake by the tree.

In addition to turf suppression, organic mulching may ameliorate allelopathic factors associated with urban soils and plant stresses. The deleterious properties of urban soils that might influence allelopathy include loss of structure; compaction; decreased aeration, drainage, and water-holding capacity; highly modified soil temperature regimes, and interrupted organic and nutrient cycling (Rietveld 1982; Craul 1994). Mulching increases water infiltration, reduces evaporation, and increases soil organic matter, resulting in improved soil structure, waterholding capacity, and nutrient availability (Watson 1988). Plants may be less sensitive to allelochemicals when environmental stresses are reduced (Einhellig 1989). The increased microbe populations fostered by the presence of organic matter could enhance decomposition of phytotoxins (Fisher 1987).

Eliminating turf by mulching or herbiciding may be beneficial to the health and survival of maturing trees as well as young plants. Fine-root development of 20-year-old trees was increased substantially with either treatment (Watson 1988). Interference from ground covers of quackgrass, tall fescue, aster, and goldenrod resulted in growth stagnation of 8- to 10-year-old black walnuts (von Althen 1985; Schlesinger and Van Sambeek 1986). Bareground turf treatments over 4 years restored tree health and growth. Reversing stagnation of 17-year-old walnuts, however, was unsuccessful (Schlesinger and Van Sambeek 1986).

\section{Avoiding Design Conflicts}

The allelopathic compatibility of trees needs to be considered when designing landscapes. For example, black walnuts are best planted in contiguous situations, either in lines or groupings, far removed from sensitive trees, especially pines and birches. Ailanthus altissima toxins have been shown to be toxic to other trees in the laboratory (Mergen 1959). Although unproven in the field, it would seem prudent to avoid new landscaping adjacent to existing Ailanthus trees. Mature sassafras (Sassafras albidum) is potentially harmful to other trees and understory plants, too (Gant and Clebsch 1975).

Consideration of allelopathy during design can provide yet another incentive to use well-drained, loam soils for ornamental plantings. Replacement of compacted clay soils prior to planting will lessen stress-toxin interaction effects significantly.

In the future, where design decisions or maintenance funding levels dictate the presence of turf around trees, allelochemical-resistant tree varieties may be available. Rink and Van Sambeek $(1985,1987)$ have shown response variability to competition and allelopathy in black walnut and white ash (Fraxinus americana) seed sources. Peters and Luu (1985) have observed that genotypes of tall fescue varied in intensity of inhibition of other species, suggesting that production of phytotoxin compounds may be genetically controlled. Reduced chemical intervention and fertilizer use in urban tree systems may result if genetic remedies can be developed in a manner similar to what has been done with tree form.

\section{Conclusions}

Allelopathy is difficult to identify, quantify, and evaluate, especially under field conditions. The interactive nature of toxin combinations and stresses further complicates the problem. Caution must be exercised in considering allelopathy as a panacea for answering difficult tree diagnostic questions. Yet there seems to be sufficient evidence to suggest that phytotoxins are capable of inhibiting tree growth by impairing nutrient uptake. Heavy soil texture appears to be a component in more obvious cases of allelopathy. Knowledge about potential ground-cover toxin influences pro- 
vides additional evidence for limiting the use of turf around trees. Amending clay soils may limit allelochemical buildup, while organic mulching may reduce allelopathic inhibition associated with environmental stress. Landscape design should include placement of allelopathically compatible plants.

Research is necessary to determine which plants are antagonistic to one another and which are complementary. Differentiating between allelopathic and competitive factors will be useful. Allelopathy complicates our understanding of competition as the determinant of plant survival and growth, which makes the topic both intriguing and controversial. However, it seems important to recognize and address allelopathy as a viable factor in research studies and arboricultural practice.

\section{Literature Cited}

Asplund, R.O. 1969. Some quantitative aspects of the phytotoxicity of monoterpenes. Weed Sci. 17: 454-455.

Buchholtz, K.P. 1971. The influence of allelopathy on mineral nutrition, pp 86-89. In US National Comm. for IBP (Eds.). Biological Interactions Among Plants. National Academcy of Science, Washington, DC.

Chick, T.A. 1991. Allelopathy in ornamental plant systems. MS Thesis. Michigan State University. $213 \mathrm{pp}$.

Craul, P.J. 1994. Urban soils: An overview and their future, pp 115-125. In Watson, G.W. and D. Neely (Eds.). The Landscape Below Ground: Proceedings of an International Workshop on Tree Root Development in Urban Soils. International Society of Arboriculture, Savoy, IL.

DeBell, D.S. 1970. Phytotoxins: New problems in forestry? J. For. 68: 335-337.

Einhellig, F.A. 1986. Mechanisms and modes of action of allelochemicals, pp 171-188. In Putnam, A.R., and C.S.Tang (Eds.). The Science of Allelopathy. Wiley and Sons, New York, NY.

Einhellig, F.A. 1989. Interactive effects of allelochemicals and environmental stress, pp 101118. In Chou, C.H., and G.R.Waller (Eds.). Phytochemical Ecology: Allelochemicals, Mycotoxins and Insect Pheromones and Allomones. Institute of Botany, Academia Sinica Monograph Series No. 9. Taipei, R.O.C.

Fales, S.L., and R.C. Wakefield. 1981. Effects of turfgrass on the establishment of woody plants. Agron. J. 73:605-610.
Fisher, R.F. 1987. Allelopathy: A potential cause of regeneration failure, pp 176-184. In Waller, G.R. (Ed.). Allelochemicals: Role in Agriculture and Forestry. American Chemical Society, Washington, DC.

Fisher, R.F. 1978. Juglone inhibits pine growth under certain moisture regimes. Soil Sci. Soc. Amer. J. 42:801-803.

Fisher, R.F., R.A. Woods, and M.R. Glavicic. 1978. Allelopathic effects of goldenrod and aster on young sugar maple. Can. J. For. Res. 8:1-9.

Gabriel, W.J. 1975. Allelopathic effects of black walnut on white birches. J. For. 73:234-237.

Gant, R.E., and E.E.C. Clebsch. 1975. The allelopathic influences of Sassafras albidum in oldfield succession in Tennessee. Ecology 56:604-615.

Green, T.L., and G.W. Watson. 1989. Effects of turfgrass and mulch on the establishment and growth of bare-root sugar maples. J. Arboric. 15:268-272.

Hoagland, R.E., and R.D. Williams. 1985. The influence of secondary plant compounds on the associations of soil microorganisms and plant roots, pp 301-325. In Thompson, A.C. (Ed.). The Chemistry of Allelopathy: Biochemical Interactions Among Plants. American Chemical Society, Washington, DC.

Horsley, S.B. 1977a. Allelopathic inhibition of black cherry by fern, grass, goldenrod, and aster. Can. J. For. Res. 7: 205-216.

Horsley, S.B. 1987. Allelopathic interference with regeneration of the Allegheny hardwood forest, $p p$ 205-213. In Waller, G.R. (Ed.). Allelochemicals: Role in Agriculture and Forestry. American Chemical Society, Washington, DC.

Mergen, F. 1959. A toxic principle in the leaves of Ailanthus. Bot. Gaz. 121:32-36.

Muller, C.H. 1969. Allelopathy as a factor in ecological process. Vegetation 18:348-357.

Perry, D.A., and C. Choquette. 1987. Allelopathic effects on mycorrhizae: Influence on structure and dynamics of forest ecosystems, pp 185-194. In Waller, G.R. (Ed.). Allelochemicals: Role in Agriculture and Forestry. American Chemical Society, Washington, DC.

Peters, E.J., and K.T. Luu. 1985. Allelopathy in tall fescue, pp 273-284. In Thompson, A.C. (Ed.). The Chemistry of Allelopathy: Biochemical Interactions Among Plants. American Chemical Society, Washington, DC.

Peterson, E.B. 1965. Inhibition of black spruce primary roots by a water-soluble substance in Kalmia augustifolia. For. Sci. 11:473-479. 
Petranka, J.W., and J.K. McPherson. 1979. The role of Rhus copallina in the dynamics of the forestprairie ecotone in north-central Oklahoma. Ecology 60:956-965.

Ponder, F., Jr. 1987. Allelopathic interference of black walnut trees with nitrogen-fixing plants in mixed plantings, pp 195-204. In Waller, G.R. (Ed.). Allelochemicals: Role in Agriculture and Forestry. American Chemical Society, Washington, DC.

Putnam, A.R., and L.A. Weston. 1986. Adverse impacts of allelopathy in agricultural systems, pp 43-56. In Putnam, A.R., and C.S.Tang (Eds.). The Science of Allelopathy.Wiley and Sons, New York, NY.

Rice, E.L. 1984. Allelopathy. Academic Press, New York, NY. $422 \mathrm{pp}$.

Rietveld, W.J. 1982. The significance of allelopathy in black walnut cultural systems. Ann. Rep. Northern Nut Growers Association 72:117-134

Rietveld, W.J., R.C. Schlesinger, and K.J. Kessler. 1983. Allelopathic effects of black walnut on European black alder coplanted as a nurse species. J. Ecol. 9:1119-1132.

Rink, G., and J.W. Van Sambeek. 1985. Variation among black walnut seedling families in resistance to competition and allelopathy. Plant Soil 88:3-10.

Rink, G., and J.W. Van Sambeek. 1987. Variation among four white ash families in response to competition and allelopathy. For. Ecol. Mgt. 18:127-134.

Schlesinger, R.C., and J.W. Van Sambeek. 1986. Ground cover management can revitalize black walnut trees. North. J. Appl. For. 3:49-51.

von Althen, F.W. 1985. Revitalizing a black walnut plantation through weed control and fertilization. For. Chron. April:71-74.

Walters, D.T., and A.R. Gilmore. 1976. Allelopathic effects of fescue on the growth of sweetgum. J. Chem. Ecol. 2:469-479.

Watson, G.W. 1988. Organic mulch and grass competition influence tree root development. J. Arboric. 14:200-203.

Weston, L.A., and A.R. Putnam. 1986. Inhibition of legume seedling growth by residues and extracts of quackgrass (Agropyron repens). Weed Sci. 34:366-372.

Acknowledgements. We appreciate the manuscript reviews and thoughtful suggestions by Stephen Horsley, Richard F. Fisher, and Frank Einhellig. Special thanks are extended to Donald I. Dickmann for his editing of the manuscript.
${ }^{1}$ Consulting Forester

844 Fairlane Court, \#6

Saginaw, Michigan 48609

\section{${ }^{2}$ Department of Forestry \\ Michigan State University \\ East Lansing, MI 48824}

Résumé. L'allélopathie est le processus par lequel les plantes produisent des toxines pour limiter la croissance des plantes d'autres espèces. Une revue de la littérature suggère que les toxines des plantes herbacées couvre-sols pourraient interférer avec l'assimilation des éléments nutritifs en endommageant ou détruisant les cellules racinaires, les poils absorbants et les mycorrhizes. La texture du sol apparaît être un élément majeur et déterminant dans la sévérité des dommages, les sols à forts contenus en argile étant les pires. Les éléments allélopathiques sont en interaction avec d'autres facteurs de compétition et de natures environnementales. L'élimination de la pelouse pour diminuer les effets allélopathiques est compatible avec les interventions culturales pour contrôler les stress environnementaux et ceux causés par la compétition des plantes.

Zusammenfassung. Alleolpathie ist der Prozess, wobei Pflanzen Toxine produzieren, die das Wachstum von anderen Pflanzenarten zu behindern. Ein Rückblick auf die Literatur zeigt, daß pflanzliche, bodenbedeckende Toxine mit der Nährstoffaufnahme interferieren, in dem sie Wurzelzellen, Wurzelhaare und Mycorrhiza beschächlich das Schadensausmaß zu beinflußen, wobei ein hoher Tonanteil besonders schlimme Auswirkungen hat. Alleolpathische Elemente sind interaktiv mit kompetitiven und unmweltbedingten Einflüßen. Das Enterfernen der Grasnarbe um Bäume zur Reduzierung von allelolpathischen verträgt sich mit anderen Kulturmaßnahmen zum Umgang mit Pflanzenkonkurrenz und umweltbedingtem Streß.

Resumen. Alelopatía es el proceso por el que las plantas producen toxinas, las cuales limitan el crecimiento de otras especies vegetales. La revisión de literatura sugiere que las toxinas de coberturas herbáceas pueden interferir con la absorción de nutrimentos dañando o destruyendo las células de las raíces, los pelos radicales y las micorrizas. La textura del suelo parece ser un factor determinante en la severidad del daño, siendo las peores aquellas con alto contenido de arcilla. Los elementos alelopáticos son interactivos con factores competitivos y ambientales. La eliminación del pasto alrededor de los árboles, con el fin de reducir los efectos alelopáticos, es consistente con los tratamientos culturales para competencia y estrés ambiental de las plantas. 